\title{
Role of Vitamin K in CKD: Is Its Supplementation Advisable in CKD Patients?
}

\author{
Patrycja Grzejszczak Ilona Kurnatowska
}

Department of Internal Medicine and Nephrology Transplantation, 1st Chair of Internal Medicine, Medical University of Lodz, Lodz, Poland

\section{Keywords}

Chronic kidney disease · Matrix Gla protein - Vitamin K

\begin{abstract}
Background: Patients with CKD are at an increased risk of developing vascular calcification (VC) and bone complications which translate into a higher morbidity and mortality. The dephosphorylated and uncarboxylated matrix Gla protein (dp-ucMGP) is considered to be an indicator of vitamin K2 status and correlates with markers of VC. It is activated by $\mathrm{Y}$-glutamyl carboxylase that converts inactive MGP into an active form, and vitamin $\mathrm{K} 2$ is a cofactor of this reaction. The active form of MGP is a known inhibitor of arterial wall calcification and plays an important role in bone turnover. Recent studies show poor vitamin K2 status in CKD patients. We aimed to review the literature for the association between vitamin K2 status and calcification and bone disease risk and the efficacy of vitamin K2 supplementation in CKD population. Summary: Most CKD patients, including those on renal replacement therapy, have vitamin K2 deficiency. The dpucMGP level, a marker of vitamin K2 status, is decreased by vitamin $\mathrm{K} 2$ supplementation in CKD patients, but there is no unequivocal proof that it influences arterial calcification progression and bone complications. Key Messages: CKD popu-
\end{abstract}

karger@karger.com www.karger.com/kbr

Karger $\stackrel{\text { ' }}{5}$
(C) 2021 The Author(s)

Published by S. Karger AG, Basel

This is an Open Access article licensed under the Creative Commons Attribution-NonCommercial-4.0 International License (CC BY-NC) (http://www.karger.com/Services/OpenAccessLicense), applicable to the online version of the article only. Usage and distribution for commercial purposes requires written permission. lation are at risk of vitamin $\mathrm{K}$ deficiency. Supplementation of vitamin $\mathrm{K} 2$ is safe and improves the serum markers of its deficiency. There is lack of strong evidence that vitamin K2 supplementation slows progression of calcification or reduces the frequency of bone complications. More prospective studies are needed.

(c) 2021 The Author(s)

Published by S. Karger AG, Basel

\section{Introduction}

Mineral disturbances lead to bone disorders and vascular calcification (VC) which are common complications in patients with CKD [1]. Cardiovascular (CV) events in CKD are the most often cause of morbidity and mortality in this population [2]. At the basis of their development lie many different triggering factors such as atherosclerosis and VC [3-5]. Patients with CKD are far more likely to die from a cardiovascular disease (CVD) than to progress to end-stage kidney disease [6]. As kidney function declines, phosphate retention occurs. Phosphate is a key signaling molecule mediating the conversion of vascular smooth muscle cells to osteoblast-like cells that produce bone matrix proteins that mediate arterial wall mineralization [7]. Abnormal circulating levels

Correspondence to:

Ilona Kurnatowska, ilona.kurnatowska@umed.lodz.pl 
of calcium, phosphorus, parathyroid hormone, vitamin $\mathrm{D}$, and fibroblast growth factor 23 may lead to the development of CKD-mineral bone disorder in CKD population [8-10]. Some studies present that hyperphosphatemia and elevated fibroblast growth factor 23 levels are associated with a higher aortic and coronary calcification scores in CKD $[11,12]$ and with increased mortality [13]. Also, protein Klotho deficiency, which is a typical phenomenon in $\mathrm{CKD}$, may cause $\mathrm{VC}$ due to simplified entry of phosphorus into vascular smooth muscle cells, causing arteriosclerosis, bone disturbances, and CKD progression [14]. A possible role of sclerostin should be considered as well due to the involvement of the Wnt signaling in the development and progression of atherosclerosis [15]. However, the data on potential consequences of increased sclerostin levels in CKD patients are unequivocal [16-18]. And, as far as we know, there are no data proving any relationship between vitamin $\mathrm{K}$ and sclerostin.

There is a lot of ongoing intensive research on the ways whereby to inhibit VC and bone complications in CKD patients [19-22]. It has been suggested that vitamin K2 may play an important role both in pathogenesis and prevention of those complications. Vitamin $\mathrm{K}$ comprises a group of fat-soluble compounds that vary in length and degree of oxygenation of side chains. There are 2 forms of vitamin K: phylloquinone (K1) and menaquinone (K2). Menadione (vitamin K3) is a synthetic analog of vitamin $\mathrm{K}$. The main sources of vitamin $\mathrm{K} 1$ are green vegetables such as spinach, broccoli, and brussels sprout [22]. Vitamin $\mathrm{K} 2$ is produced by intestinal bacteria and fermented products like cheese, butter, and a Japanese soybean product called natto are rich in this vitamin. Moreover, vitamin $\mathrm{K} 2$ can be found in egg yolk, poultry, and liver $[22,23]$. Vitamin $\mathrm{K}$ is absorbed in the small intestine and packaged into chylomicrons secreted into the lymphatic system and passed via the thoracic duct to the blood system [24].

\section{Vitamin $\mathrm{K}$ in Calcification Process and Bone Metabolism}

Both forms of vitamin $\mathrm{K}$ take part in essential metabolic processes: vitamin $\mathrm{K} 1$ is significantly active in the liver where it catalyzes the reaction of clotting protein activation, while vitamin $\mathrm{K} 2$ catalyzes protein carboxylation peripherally among others in blood vessel walls and bones. Smooth muscle cells and chondrocytes produce an inhibitor of VC called matrix Gla protein (MGP) [25-27]. MGP goes through 2 types of reactions in the posttransla- tion process: phosphorylation and carboxylation $[28,29]$. Four forms of MGP can be detected in circulation, and the level of dephosphorylated and uncarboxylated MGP (dp-ucMGP) is considered to be a marker of vitamin K2 status [22]. The activity of MGP depends on $\gamma$-glutamyl carboxylase that converts inactive uncarboxylated MGP (ucMGP) to active carboxylated form (cMGP), and vitamin K2 is a cofactor of this reaction [22]. Some studies show a relationship between low vitamin $\mathrm{K}$ concentration and higher CVD risk [30] and calcification [31]. It seems that fully active MGP is crucial for maintaining vascular wall integrity by avoiding calcification. Active MGP may inhibit artery calcification through several pathophysiological mechanisms. It binds calcium and phosphorus ions and seems to have a high binding affinity to forming hydroxyapatite crystals thus preventing their accumulation within the arterial wall [32]. Moreover, thanks to binding with calcium and phosphate crystals, it prevents their deposition in the artery walls; furthermore, it stimulates the arterial macrophages to phagocytosis and apoptosis of the MGP-hydroxyapatite complex [32]. The mechanism of VC development and the link between calcification process and vitamin K2 are shown in Figure 1. That is why it is suggested that deficiency of vitamin K2 plays a significant role in pathogenesis of calcification and calciphylaxis. Vitamin K deficiency suppresses vitamin $\mathrm{K}$-dependent proteins to obtain their carboxylated form which enables them to bind calcium ions which is crucial both for proper bone mineralization and VC prevention [33]. Using vitamin $\mathrm{K}$ antagonists (VKAs) prevents VC which indirectly testifies to the important role of vitamin $\mathrm{K}$ in this process $[29,34]$. Coumarins by blocking peripheral $\gamma$-carboxylation of vitamin K-dependent proteins including MGP in vascular tissues [34] promote VC [29]. In a rat model, warfarin caused acute medial calcification of major arteries and markedly increased the expression levels of MGP mRNA and protein in calcified arteries and decreased serum levels of MGP [35]. A similar association between treatment with VKAs and calcification was observed in clinical studies in general population [36-38] and in CKD patients [39]. There is also a report of a case of massive calcification developed during warfarin use in a kidney transplanted (KTx) patient [40]. There are reports that lack of vitamin $\mathrm{K} 2$ is connected with a greater risk of atherosclerosis, osteoporosis, Alzheimer disease, and cancer [41]. Some research demonstrated that high level of dp-ucMGP (which indirectly provides information about low supplies of vitamin K2) accompanies greater calcification both in general population and in patients in all stages of CKD [42, 43]. dp-ucMGP level varies 


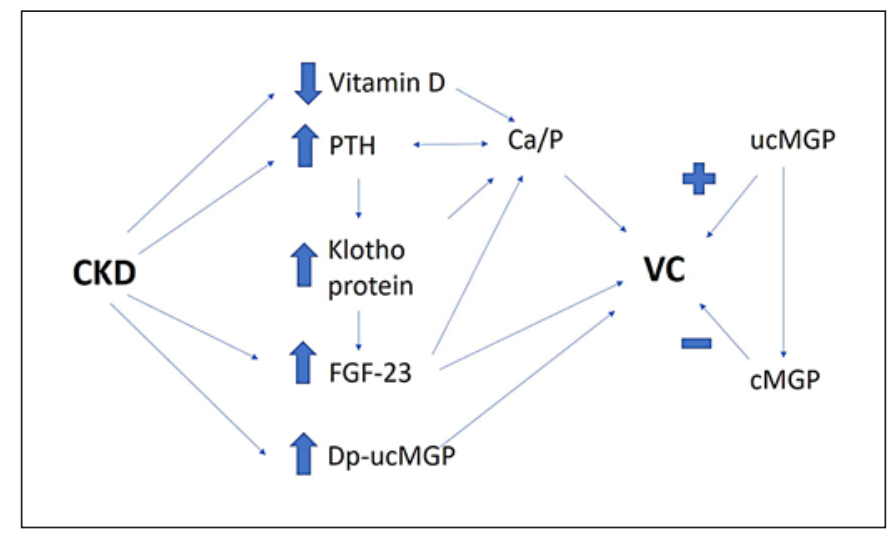

Fig. 1. Pathophysiology of calcification in $\mathrm{CKD}$ and role of vitamin $\mathrm{K}$ in its process. $\mathrm{CKD}$ influences $\mathrm{VC}$ through calcium $(\mathrm{Ca})$ and phosphorus (P) metabolism disturbances, high levels of FGF-23, $\mathrm{PTH}$, low concentration of Klotho protein, and also disturbances in carboxylation of K-dependent proteins like MGP. Vitamin D deficiency and further hypocalcemia, together with hyperphosphatemia, stimulate FGF-23 and PTH secretion. These factors promote VC by higher deposition of hydroxyapatite in the extracellular matrix. High concentration of FGF-23 also may suppress renal 1a-hydroxylase expression, reducing its ability to activate vitamin $\mathrm{D}$ in kidney proximal tubules and subsequently impairing calcium absorption. $\boldsymbol{\alpha}$-Klotho protein, whose level is low in CKD, may cause VC due to simplified entry of phosphorus into vascular smooth muscle cells. Active MGP binds calcium and phosphorus ions and seems to have a high binding affinity to forming hydroxyapatite crystals, thus preventing their accumulation within the arterial wall, and furthermore stimulates the arterial macrophages to phagocytosis and apoptosis of the MGP-hydroxyapatite complex. The activity of MGP depends on $\gamma$-glutamyl carboxylase that converts inactive ucMGP to active cMGP, and vitamin $\mathrm{K} 2$ is a cofactor of this reaction. Deficiency of vitamin K2 leads to increase in the level of dp-ucMGP, which also rises with the deterioration of kidney function. VC, vascular calcification; FGF-23, fibroblast growth factor 23; PTH, parathyroid hormone; MGP, matrix Gla protein; ucMGP, uncarboxylated MGP; cMGP, carboxylated MGP; dp-ucMGP, dephosphorylated and uncarboxylated MGP.

from 400 to $500 \mathrm{pmol} / \mathrm{L}$ in general population [19]; however, it is not clear what value should be considered as optimal. No biochemical parameter reflects the tissue bioavailability of vitamin K. dp-ucMGP concentration rises with the advance of CKD $[29,44]$.

The active form of MGP also inhibits the binding of bone morphogenic protein-2 to its receptor, thus blocking its chondrogenesis, osteogenesis, and calcification function [29, 32]. The expression of MGP is 5-fold greater in the kidneys than bones [45], so it can be assumed that kidney insufficiency may lead to pathological expression of the protein signifying higher risk of calcification. Vitamin K2 is also a cofactor of osteocalcin (OC) $\gamma$-carboxylation. Uncarboxylated $\mathrm{OC}(\mathrm{ucOC})$ is an en- zyme of bone metabolism, and its high concentration is an indirect indicator of vitamin $\mathrm{K} 2$ deficit $[46,47]$. Holden et al. [48] examined 172 patients with CKD in stage $3-5$ and observed that $6 \%$ had shortage of vitamin K1 with phylloquinone measured in blood plasma $(<0.4 \mathrm{ng} /$ $\mathrm{mL}$ ) and as many as $60 \%$ had deficit of vitamin $\mathrm{K} 2$ when measured by ucOC level ( $>20 \%$ ucOC). Low serum OC level in hemodialyzed (HD) patients is connected with a higher risk of CV events [49]. Westenfeld et al. [19] showed that HD patients have 4.5-fold higher dp-ucMGP and 8.4-fold higher ucOC level than people with good kidney function. It is suggested that lack of vitamin K2 may lead to greater risk of atherosclerosis, calcification, and calciphylaxis and may augment vascular complications in CKD patients. Kohlmeier et al. [50] were the first to demonstrate independent correlation between low vitamin $\mathrm{K}$ level and higher bone break risk in HD patients. Similarly, Fusaro et al. [51] examined 387 HD patients where $50 \%$ had a broken spine, and a decreased phylloquinone level $(<0.21 \mathrm{ng} / \mathrm{mL})$ was its predictor. They also demonstrated that HD patients treated with warfarin for at least a year have a greater risk of spine fracture than those who do not take the VKA [39].

\section{Vitamin K2 Deficiency in CKD Population}

Dp-ucMGP level rises with the advance of CKD and is associated with albuminuria $[52,53]$. Patients treated with renal replacement therapy (mainly dialyzed) are particularly vulnerable to vitamin $\mathrm{K} 2$ deficiency $[54,55]$. It can be related to dietary limitations in CKD such as elimination of foods with high vitamin $\mathrm{K} 2$ content (meat, eggs, and cheese - foods with high content of phosphorus) $[54,55]$. Vitamin K deficiency in CKD can be magnified by the uremic milieu which leads to gut dysbiosis, common in CKD population [56], with a consequent decrease in vitamin K2 production. Due to the fact that vitamin $\mathrm{K} 2$ resources depend on proper microbiome function, any abnormality there may also be a cause of vitamin $\mathrm{K}$ deficiency; however, it has not been well studied yet. The elevated vitamin K2 usage in metabolic processes such as VC inhibition and proper bone condition, the influence of the uremic toxins on the vitamin $\mathrm{K} 2$ cycle, and the decreased absorption due to phosphorate binder intake may be other causes of vitamin $\mathrm{K}$ deficiency $[57,58]$. The VIKI study showed that treatment with sevelamer was connected with higher rate of menaquinone deficiency and aortic and iliac calcification [51]. Antibiotic therapy and widely used proton pomp inhibitors may also 
result in vitamin $\mathrm{K}$ deficiency [59]. Peritoneal dialysis (PD) patients may also have a deficit of vitamin K2 measured by dp-ucMGP concentration [60]. Qingdong Xu et al. [60] examined $158 \mathrm{PD}$ patients, where the group with higher dp-ucMGP level (>1,093 pmol/L) was older, more frequently exhibited valve calcification, and also had a significantly higher risk of new $\mathrm{CV}$ events including brain stroke and a higher mortality rate. Jansz et al. [61] showed that KTx patients have significantly lower dp-ucMGP compared to the HD and PD ones. However, Keyzer et al. [20] found that $91 \%$ of KTx patients have vitamin K2 insufficiency, and higher level of dp-ucMGP is a risk factor of death in KTx patients. Some studies show as well that deficiency of both vitamin $\mathrm{D}$ and $\mathrm{K}$, as compared to their better status, is linked with higher graft failure risk and mortality [62]. These observations should perhaps be further followed by randomized trials investigating whether vitamin $\mathrm{K}$ supplementation might lead to improved outcomes after KTx.

Calciphylaxis is a quite rare image of VC in CKD patients, affecting the skin and subcutaneous tissue in dialysis patients, and vitamin K2 deficiency may also play a role in its pathogenesis. Calciphylaxis in HD patients is associated with significant reduction of vitamin $\mathrm{K} 2$ level determined by cMGP level, necessary to inhibit VC [42, 63]. In the study by Nigwekar et al. [42, 63], HD patients with calciphylaxis had higher plasma levels of ucMGP and cMGP than HD subjects without this complication; however, relative cMGP was lower. Patients not taking warfarin had a similarly lower relative cMGP concentration. Each 0.1-unit reduction in cMGP concentration is associated with a $>2$-fold increase in calciphylaxis risk [42]. The authors concluded that vitamin K deficiencymediated reduction in relative $\mathrm{cMGP}$ concentration may play a role in the pathogenesis of calciphylaxis, and vitamin $\mathrm{K}$ supplementation can prevent and/or treat calciphylaxis [42]. Its supplementation may have potential preventive or even therapeutic effect. It has been already tested in a few clinical trials, for example, in the clinical trial (NCT02278692), where dialysis patients received vitamin $\mathrm{K} 1$ in dose $10 \mathrm{mg}$ orally 3 times a week after dialysis for 12 weeks; however, final results are still awaited.

\section{Efficacy of Vitamin K2 Supplementation in CKD Population}

Some studies suggest that high dietary menaquinone intake in general population has beneficial effect in case of CVD $[64,65]$ and together with supplementation with vitamin $\mathrm{K}$ for bone density and lower bone break risk [66-70]; however, the reports are not unequivocal. A Rotterdam study examined 4,800 patients and concluded that decreased amount of vitamin $\mathrm{K} 2$ in diet was bound with a higher risk of aortic calcification, CV incidence, and mortality in general population [67]. Slowing down of calcification progression is a potential beneficial effect of vitamin K2 supplementation [21]. On the other hand, Fulton et al. [71] showed no significant effect of vitamin $\mathrm{K} 2$ supplementation on vascular health in older people with vascular disease; however, that study had a few limitations, and one of them was that the patients received only $100 \mu \mathrm{g}$ of vitamin K2. There are also some reports that supplementation of vitamin K2 may affect metabolic processes - it increases insulin sensitivity index $[72,73]$ and decreases fasting glucose and 2-h post-OGTT glucose [74]. On the other hand, there are also reports showing no effect on insulin resistance $[75$, 76].

Despite numerous studies, it has not been established what form, dosage, or duration of vitamin K2 supplementation is advisable, if at all, in general population and CKD patients. There are a few different chemical variants of vitamin $\mathrm{K} 2$, and their name is determined by the number of side chains. Menaquinone-4 (MK-4) and MK-7 forms are commercially used in supplementation. MK-7 has longer half-life and has more stable concentration in plasma achieved in the second week of supplementation [77]. It was shown that administration of phylloquinone has no influence on dp-ucMGP level, whereas an inversely proportional impact is observed for menaquinone [55]. Caluwe et al. [55] supplemented HD patients with 360,720 , and 1,080 $\mu \mathrm{g}$ of MK-7, 3 times a week for 8 weeks. They noticed a decrease in dp-ucMGP level by 17,33 , and $46 \%$, respectively, and they suggest a possibility of a better effect with a higher dose of vitamin $\mathrm{K} 2$ [55], but the changes in VC were not investigated in their study. Brandenburg et al. [78] observed that HD patients supplemented with vitamin K1 had significantly lower dp-ucMGP level (by 45\%) with slower progression of aortic valve calcification compared with patients without such supplementation. In a recently published study, HD patients were supplemented with MK-7 in a dose of $200 \mu \mathrm{g}$ every day over 1 year. The authors did not observe any benefit of vitamin K2 supplementation on aortic calcification despite a decrease of serum level of ucMGP [79].

In the study by Kurnatowska et al. [80], non-HD patients with CKD stage 3-5 were supplemented with $10 \mu \mathrm{g}$ of cholecalciferol with or without of $90 \mu \mathrm{g} /$ day of 
vitamin K2. After 9 months, a slower progression of atherosclerosis was observed in the group receiving MK-7, with no significant difference in calcification progress. However, in some patients, a slower progression of calcification of the coronary artery was noted in the group taking both vitamin $\mathrm{K}$ and $\mathrm{D}$ compared to vitamin $\mathrm{D}$ only [80]. A significant drop of dp-ucMGP level was observed in 3-5 stage CKD patients who received vitamin K2 [44]. Maybe a longer supplementation of vitamin K2 would have caused a visible difference in inhibition of VC. Witham et al. [81] recently published a report on a study where they also supplemented CKD stage $3 \mathrm{~b}-4$ patients with MK-7 in a dose of $400 \mu \mathrm{g} /$ day over 1 year. The authors noted a reduction of dp-ucMGP and OC levels together with improvement of insulin resistance, but they did not observe any reduction of vascular stiffness or calcification [81]. In the study by Zwakenberg et al. [82], supplementation with MK-7 (360 $\mu$ g/day) for 6 months in patients with type 2 diabetes and CVD did not significantly change the calcification score of both femoral arteries compared with placebo treatment. Mansour et al. [83] found that 53\% of KTx patients had a subclinical vitamin $\mathrm{K}$ deficiency, and supplementation with $360 \mu \mathrm{g}$ once daily of MK-7 for 8 weeks reduced the dp-ucMGP level by $55 \%$ and subclinical vitamin K deficiency by $40 \%$. Furthermore, they noticed that improvement in arterial stiffness was independently associated with the reduction in dp-ucMGP concentration [83]. Summarizing, it seems that higher dietary vitamin K consumption is associated with a significantly lower risk of coronary artery disease, but the effects of vitamin $\mathrm{K} 2$ supplementation on the progression of VC are still ambiguous and require randomized studies and longer observation.

There are many studies estimating the influence of vitamin $\mathrm{K}$ intake on bone and vascular metabolism in general population with the use of different preparations and doses, achieving different final results [22]. Some studies, performed in general population, present positive effects of vitamin K2 intake: reduced loss of bone mineral density [84-88], including steroid induced [89], and significant fracture reduction [90,91], whereas other research studies do not confirm those effects [9296]. However, there have been no prospective studies assessing the long-term influence of vitamin K2 supplementation on bone complication in the CKD population. In order to establish the actual value of vitamin K2 supplementation, further extensive prospective studies with randomization and prolonged follow-up are necessary.

Vitamin K in CKD Patients

\section{Safety of Vitamin K2 Supplementation}

Nevertheless, vitamin K supplementation seems to be safe to administer. Regardless of the dose applied, adverse effects were insignificant - of gastrointestinal nature mainly - probably due to specific unpleasant scent of the preparation. No greater risk of thrombosis has been so far observed in patients on vitamin K2 supplementation [96]. Theuwissen et al. [97] examined 42 healthy men and women allocating them to 1 of 7 groups receiving placebo or vitamin $\mathrm{K} 2$ at a dose of 10, 20, 45, 90,180 , or $360 \mu \mathrm{g} /$ day. With an increase of the dose, decreased dp-ucMGP concentration was noted, and the dose $90 \mu \mathrm{g} /$ day proved to be clinically significant compared to the placebo group; no thrombogenic side effects were observed [97]. Theuwissen et al. [98] also studied the effect of simultaneous use of VKA and vitamin K2 supplementation in healthy people. The study showed that supplementation with vitamin $\mathrm{K} 2$ at dose $10 \mu \mathrm{g}$ (lower than the commonly used dose of $45 \mu \mathrm{g}$ ) resulted in an increased sensitivity to the used anticoagulation in some participants; therefore, supplementation with vitamin K2 should be avoided in persons taking VKA [98]. De Vriese et al. [99] in their study divided patients into 3 groups using VKA, rivaroxaban, and rivaroxaban with supplementation of vitamin K2. They showed that dpucMGP level was significantly lower in the group receiving rivaroxaban and even more so in the group using rivaroxaban together with vitamin $\mathrm{K} 2$. However, no influence of vitamin K2 supplementation on progression of calcification was noted [99]. It seems that rivaroxaban is safe at the dose of $10 \mathrm{mg}$ in HD patients, and the frequency of ischemic or hemorrhagic stroke did not differ between rivaroxaban alone and rivaroxaban with vitamin K2 groups, and hemorrhagic stroke was only reported in the VKA group [99]. Still, the findings should be confirmed by a larger study with more powerful statistical significance.

\section{Conclusion}

There are intensive ongoing studies focusing on the role of vitamin $\mathrm{K}$, especially $\mathrm{K} 2$, in pathogenesis of $\mathrm{CV}$ and bone complications in patients in different CKD stages including patients treated with renal replacement therapy. The level of dp-ucMGP, an indirect marker of vitamin K2 deficiency, significantly decreases with vitamin K2 supplementation, but so far it has not been proven that such supplementation may slow progression of

Kidney Blood Press Res 2021;46:523-530 527 
calcification or reduce the frequency of bone complications. There is still want of randomized and prospective studies evaluating the clinical benefits of vitamin K2 supplementation in CKD patients.

\section{Conflict of Interest Statement}

The authors declare no conflicts of interest.

\section{Funding Sources}

This research received no external funding.

\section{Author Contributions}

P.G. searched the literature and wrote the manuscript; I.K. searched the literature, wrote the conclusion, and critically reviewed and corrected the manuscript.

\section{References}

1 Schlieper G, Schurgers L, Brandenburg V, Reutelingsperger $\mathrm{C}$, Floege J. Vascular calcification in chronic kidney disease: an update. Nephrol Dial Transplant. 2016 Jan;31(1):319

2 Sarnak MJ, Levey AS, Schoolwerth AC, Coresh J, Culleton B, Hamm LL, et al. Kidney disease as a risk factor for development of cardiovascular disease: a statement from the American heart association councils on kidney in cardiovascular disease, high blood pressure research, clinical cardiology, and epidemiology and prevention. Circulation. 2003 Nov;108(5):2154-69.

3 Paloian NJ, Giachelli CM. A current understanding of vascular calcification in CKD. Am J Physiol Renal Physiol. 2014 Oct;307(8): F891-900.

4 Rocha-Singh KJ, Zeller T, Jaff MR. Peripheral arterial calcification: prevalence, mechanism, detection, and clinical implications. Catheter Cardiovasc Interv. 2014 May;83(6):E212-20.

5 Guerin AP, London GM, Marchais SJ, Metivier F. Arterial stiffening and vascular calcifications in end-stage renal disease. Nephrol Dial Transplant. 2000 Jul;15(7):1014-21.

6 Dalrymple LS, Katz R, Kestenbaum B, Shlipak MG, Sarnak MJ, Stehman-Breen C, et al. Chronic kidney disease and the risk of endstage renal disease versus death. J Gen Intern Med. 2011 Apr;26(4):379-85.

7 Leopold JA. Vascular calcification: mechanisms of vascular smooth muscle cell calcification. Trends Cardiovasc Med. 2015 May; 25(4):267-74.

8 Covic A, Vervloet M, Massy ZA, Torres PU, Goldsmith D, Brandenburg V, et al. Bone and mineral disorders in chronic kidney disease: implications for cardiovascular health and ageing in the general population. Lancet Diabetes Endocrinol. 2018 Apr;6(4):319-31.

9 Cianciolo G, Galassi A, Capelli I, Schillaci R, La Manna G, Cozzolino M. Klotho-FGF23, cardiovascular disease, and vascular calcification: black or white? Curr Vasc Pharmacol. 2018 Jan;16(2):143-56.

10 Cozzolino M, Ciceri P, Galassi A, Mangano M, Carugo S, Capelli I, et al. The key role of phosphate on vascular calcification. Toxins. 2019 Apr;11(4):213.
11 Desjardins L, Liabeuf S, Renard C, Lenglet A, Lemke HD, Choukroun G, et al. FGF23 is independently associated with vascular calcification but not bone mineral density in patients at various CKD stages. Osteoporos Int. 2012 Jul;23(7):2017-25.

12 Zhang M, Yan J, Zhu M, Ni Z. Fibroblast growth factor 23 predicts coronary calcification and poor prognosis in patients with chronic kidney disease stages 3-5D. Ann Clin Lab Sci. 2015;45(1):17-22.

13 Gutiérrez OM, Mannstadt M, Isakova T, Rauh-Hain JA, Tamez H, Shah A, et al. Fibroblast growth factor 23 and mortality among patients undergoing hemodialysis. N Engl J Med. 2008 Aug;359(6):584-92.

14 Villanueva LS, González CS, Tomero JAS, Aguilera A, Junco EO. Bone mineral disorder in chronic kidney disease: Klotho and FGF23; cardiovascular implications. Nefrologia. 2016 Jul-Aug;36(4):368-75.

15 Brandenburg VM, Verhulst A, Babler A, D'Haese PC, Evenepoel P, Kaesler N. Sclerostin in chronic kidney disease-mineral bone disorder think first before you block it! Nephrol Dial Transplant. 2019 Mar;34(3): 408-14.

16 Jrrrgensen HS, Winther S, Dupont L, Břttcher M, Rejnmark L, Hauge EM, et al. Sclerostin is not associated with cardiovascular event or fracture in kidney transplantation candidates. Clin Nephrol. 2018 Jul;90(1):18-26.

17 Gonçalves FL, Elias RM, dos Reis LM, Graciolli FG, Zampieri FG, Oliveira RB, et al. Serum sclerostin is an independent predictor of mortality in hemodialysis patients. BMC Nephrol. 2014 Dec;15:190.

18 Wang XR, Yuan L, Zhang JJ, Hao L, Wang DG. Serum sclerostin values are associated with abdominal aortic calcification and predict cardiovascular events in patients with chronic kidney disease stages 3-5D. Nephrology. 2017 Apr;22(4):286-92.

19 Westenfeld R, Krueger T, Schlieper G, Cranenburg EC, Magdeleyns EJ, Heidenreich $S$, et al. Effect of vitamin K2 supplementation on functional vitamin $\mathrm{K}$ deficiency in hemodialysis patients: a randomized trial. Am J Kidney Dis. 2012 Feb;59(2):186-95.
20 Keyzer CA, Vermeer C, Joosten MM, Knapen MH, Drummen NE, Navis G, et al. Vitamin K status and mortality after kidney transplantation: a cohort study. Am J Kidney Dis. 2015 Mar;65(3):474-83.

21 Shea MK, O’Donnell CJ, Hoffmann U, Dallal GE, Dawson-Hughes B, Ordovas JM, et al. Vitamin $\mathrm{K}$ supplementation and progression of coronary artery calcium in older men and women. Am J Clin Nutr. 2009 Jun;89(6): 1799-807.

22 Caluwe R, Verbeke F, De Vriese S. Evaluation of vitamin $\mathrm{K}$ status and rationale for vitamin $\mathrm{K}$ supplementation in dialysis patients. Nephrol Dial Transplant. 2020 Jan;35(1):2333.

23 Elder SJ, Haytowitz DB, Howe J, Peterson JW, Booth SL. Vitamin K contents of meat, dairy, and fast food in the US diet. J Agric Food Chem. 2006 Jan;54(2):463-7.

24 Ji Y, Li X, Tso P. Intestinal fatty acid absorption. Immunol Endocr Metab Agents Med Chem. 2009;9(1):60-73.

25 Luo G, Ducy P, McKee MD, Pinero GJ, Loyer E, Behringer RR, et al. Spontaneous calcification of arteries and cartilage in mice lacking matrix GLA protein. Nature. 1997 Mar; 386(6620):78-81.

26 Munroe PB, Olgunturk RO, Fryns JP, Van Maldergem L, Ziereisen F, Yuksel B, et al. Mutations in the gene encoding the human matrix Gla protein cause Keutel syndrome. Nat Genet. 1999 Jan;21(1):142-4.

27 Teebi AS, Lambert DM, Kaye GM, Al-Fifi S, Tewfik TL, Azouz EM. Keutel syndrome: further characterization and review. Am J Med Genet. 1998 Jun;78(2):182-7.

28 Wallin R, Cain D, Hutson SM, Sane DC, Loeser R. Modulation of the binding of matrix Gla protein (MGP) to bone morphogenetic protein-2 (BMP-2). Thromb Haemost. 2000 Dec;84(6):1039-44.

29 Schurgers LJ, Spronk HM, Skepper JN, Hackeng TM, Shanahan CM, Vermeer C, et al. Post-translational modifications regulate matrix Gla protein function: importance for inhibition of vascular smooth muscle cell calcification. J Thromb Haemost. 2007 Dec;5(12): 2503-11. 
30 Mayer O, Seidlerová J, Wohlfahrt P, Filipovský J, Vaněk J, Cífková R, et al. Desphospho-uncarboxylated matrix Gla protein is associated with increased aortic stiffness in a general population. J Hum Hypertens. 2016; 30(7):418-23.

31 Wuyts J, Dhondt A. The role of vitamin K in vascular calcification of patients with chronic kidney disease. Acta Clin Belg. 2016 Dec; 71(6):462-7.

32 Shanahan CM. Mechanisms of vascular calcification in renal disease. Clin Nephrol. 2005 Feb;63(2):146-57.

33 Fusaro M, Cianciolo C, Evenepoel P, Schurgers L, Plebani M. Vitamin K in CKD bone disorders. Calcif Tissue Int. 2021 Apr;108(4): 476-85.

34 Danziger J. Vitamin K-dependent proteins, warfarin, and vascular calcification. Clin J Am Soc Nephrol. 2008 Sep;3(5):1504-10.

35 Price PA, Faus SA, Williamson MK. Warfarin causes rapid calcification of the elastic lamellae in rat arteries and heart valves. Arterioscler Thromb Vasc Biol. 1998 Sep;18(9): $1400-7$.

36 Han KH, O’Neill WC. Increased peripheral arterial calcification in patients receiving warfarin. J Am Heart Assoc. 2016 Jan;5(1): e002665.

37 Koos R, Krueger T, Westenfeld R, Kühl HP, Brandenburg V, Mahnken AH, et al. Relation of circulating matrix Gla-protein and anticoagulation status in patients with aortic valve calcification. Thromb Haemost. 2009 Apr; 101(4):706-13.

38 Palaniswamy C, Aronow WS, Sekhri A, Adapa S, Ahn C, Singh T, et al. Warfarin use and prevalence of coronary artery calcification assessed by multislice computed tomography. Am J Ther. 2014 May-Jun;21(3):148-51.

39 Fusaro M, Tripepi G, Noale M, Plebani M, Zaninotto M, Piccoli A, et al. Prevalence of vertebral fractures, vascular calcifications, and mortality in warfarin treated hemodialysis patients. Curr Vasc Pharmacol. 2015;13(2): 248-58.

40 Hristova M, van Beek C, Schurgers LJ, Lanske $B$, Danziger J. Rapidly progressive severe vascular calcification sparing the kidney allograft following warfarin initiation. Am J Kidney Dis. 2010 Dec;56(6):1158-62.

41 Roumeliotis S, Dounousi E, Eleftheriadis T, Liakopoulos V. Association of the inactive circulating matrix Gla protein with vitamin $\mathrm{K}$ intake, calcification, mortality, and cardiovascular disease: a review. Int J Mol Sci. 2019 Feb; 20(3):628.

42 Nigwekar SU, Bloch DB, Nazarian RM, Vermeer C, Booth SL, Xu D, et al. Vitamin Kdependent carboxylation of matrix Gla protein influences the risk of calciphylaxis. J Am Soc Nephrol. 2017 Jun;28(6):1717-22.

43 Silaghi CN, Ilyés T, Filip VP, Farcaș M, van Ballegooijen AJ, Crăciun AM. Vitamin K dependent proteins in kidney disease. Int J Mol Sci. 2019 Apr;20(7):1571.
44 Kurnatowska I, Grzelak P, Masajtis-Zagajewska A, Kaczmarska M, Stefańczyk L, Vermeer C, et al. Plasma desphospho-uncarboxylated matrix Gla protein as a marker of kidney damage and cardiovascular risk in advanced stage of chronic kidney disease. Kidney Blood Press Res. 2016 Apr;41(3):231-9.

45 Fraser JD, Price PA. Lung, heart, and kidney express high levels of mRNA for the vitamin $\mathrm{K}$-dependent matrix Gla protein. Implications for the possible functions of matrix Gla protein and for the tissue distribution of the gamma-carboxylase. J Biol Chem. 1988 Aug; 263(23):11033-6.

46 Shea MK, Booth SL. Concepts and controversies in evaluating vitamin $\mathrm{K}$ status in population-based studies. Nutrients. 2016 Jan;8(1):8.

47 Cranenburg EC, Koos R, Schurgers LJ, Magdeleyns EJ, Schoonbrood TH, Landewé RB, et al. Characterisation and potential diagnostic value of circulating matrix Gla protein (MGP) species. Thromb Haemost. 2010 Aug; 104(4): $811-22$.

48 Holden RM, Morton AR, Garland JS, Pavlov A, Day AG, Booth SL. Vitamins K and D status in stages 3-5 chronic kidney disease. Clin J Am Soc Nephrol. 2010 Apr;5(4):590-7.

49 Yamashita T, Okano K, Tsuruta Y, Akiba T, Nitta K. Serum osteocalcin levels are useful as a predictor of cardiovascular events in maintenance hemodialysis patients. Int Urol Nephrol. 2013 Feb;45(1):207-14.

50 Kohlmeier M, Saupe J, Shearer MJ, Schaefer $\mathrm{K}$, Asmus G. Bone health of adult hemodialysis patients is related to vitamin $\mathrm{K}$ status. Kidney Int. 1997 Apr;51(4):1218-21.

51 Fusaro M, Noale M, Viola V, Galli F, Tripepi $\mathrm{G}$, Vajente N, et al. Vitamin K, vertebral fractures, vascular calcifications, and mortality: vitamin K Italian (VIKI) dialysis study. J Bone Miner Res. 2012 Nov;27(11):2271-8.

52 Wei FF, Trenson S, Thijs L, Huang QF, Zhang ZY, Yang WY, et al. Desphospho-uncarboxylated matrix Gla protein is a novel circulating biomarker predicting deterioration of renal function in the general population. Nephrol Dial Transplant. 2018 Jul;33(7):1122-8.

53 Groothof D, Post A, Sotomayor CG, Keyzer CA, Flores-Guerero JL, Hak E, et al. Functional vitamin $\mathrm{K}$ status and risk of incident chronic kidney disease and microalbuminuria: a prospective general population-based cohort study. Nephrol Dial Transplant. 2020 Dec 13: gfaa304.

54 Cranenburg EC, Schurgers LJ, Uiterwijk HH, Beulens JW, Dalmeijer GW, Westerhuis R, et al. Vitamin $\mathrm{K}$ intake and status are low in hemodialysis patients. Kidney Int. 2012 Sep; 82(5):605-10.

55 Caluwe R, Vandecasteele S, Van Vlem B, Vermeer C, De Vriese AS, et al. Vitamin K2 supplementation in haemodialysis patients: a randomized dose-finding study. Nephrol Dial Transplant. 2013 Jul;29(7):1385-90.

56 Evenepoel P, Poesen R, Meijers B. The gutkidney axis. Pediatr Nephrol. 2017 Nov; 32(11):2005-14.
57 Kaesler N, Magdeleyns E, Herfs M, Schettgen $\mathrm{T}$, Brandenburg V, Fliser D, et al. Impaired vitamin $\mathrm{K}$ recycling in uremia is rescued by vitamin K supplementation. Kidney Int. 2014 Aug;86(2):286-93.

58 Neradova A, Schumacher SP, Hubeek I, Lux P, Schurgers LJ, Vervloet MG. Phosphate binders affect vitamin $\mathrm{K}$ concentration by undesired binding, an in vitro study. BMC Nephrol. 2017 May;18(1):149.

59 Shevchuk YM, Conly JM. Antibiotic-associated hypoprothrombinemia: a review of prospective studies, 1966-1988. Rev Infect Dis. 1990 Nov-Dec;12(6):1109-26.

60 Xu Q, Guo H, Cao S, Zhou Q, Chen J, Su M, et al. Associations of vitamin $\mathrm{K}$ status with mortality and cardiovascular events in peritoneal dialysis patients. Int Urol Nephrol. 2019 Mar;51(3):527-34.

61 Jansz TT, Neradova A, van Ballegooijen AJ, Verhaar MC, Vervloet MG, Schurgers LJ, et al. The role of kidney transplantation and phosphate binder use in vitamin $\mathrm{K}$ status. PLoS One. 2018 Aug;13(8):e0203157.

62 van Ballegooijen AJ, Beulens JWJ, Keyzer CA, Navis GJ, Berger SP, de Borst MH, et al. Joint association of vitamins $\mathrm{D}$ and $\mathrm{K}$ status with long-term outcomes in stable kidney transplant recipients. Nephrol Dial Transplant. 2020 Apr;35(4):706-14.

63 Nigwekar SU, Thadhani R, Brandenburg VM. Calciphylaxis. N Engl J Med. 2018 May; 378(18):1704-14.

64 Beulens JW, Bots ML, Atsma F, Bartelink ML, Prokop M, Geleijnse JM, et al. High dietary menaquinone intake is associated with reduced coronary calcification. Atherosclerosis. 2009 Apr;203(2):489-93.

65 Geleijnse JM, Vermeer C, Grobbee DE, Schurgers LJ, Knapen MH, van der Meer IM, et al. Dietary intake of menaquinone is associated with a reduced risk of coronary heart disease: the Rotterdam Study. J Nutr. 2004 Nov; 134(11):3100-5.

66 Price CT, Langford JR, Liporace FA. Essential nutrients for bone health and a review of their availability in the average North American diet. Open Orthop J. 2012 Apr;6:143-9.

67 Feskanich D, Weber P, Willett WC, Rockett H, Booth SL, Colditz GA. Vitamin K intake and hip fractures in women: a prospective study. Am J Clin Nutr. 1999 Jan;69(1):74-9.

68 Shiraki M, Shiraki Y, Aoki C, Miura M. Vitamin K2 (menatetrenone) effectively prevents fractures and sustains lumbar bone mineral density in osteoporosis. J Bone Miner Res. 2000 Mar;15(3):515-21.

69 Iwamoto J. Vitamin $\mathrm{K}_{2}$ therapy for postmenopausal osteoporosis. Nutrients. 2014 May; 6(5):1971-80.

70 Iwamoto J, Takeda T, Sato Y. Menatetrenone (Vitamin K2) and bone quality in the treatment of postmenopausal osteoporosis. Nutr Rev. 2006 Dec;64(12):509-17. 
71 Fulton RL, McMurdo ME, Hill A, Abboud RJ, Arnold GP, Struthers AD, et al. Effect of vitamin $\mathrm{K}$ on vascular health and physical function in older people with vascular disease: a randomised controlled trial. J Nutr Health Aging. 2016 Mar;20(3):325-33.

72 Choi HJ, Yu J, Choi H, An JH, Kim SW, Park KS, et al. Vitamin K2 supplementation improves insulin sensitivity via osteocalcin metabolism: a placebo-controlled trial. Diabetes Care. 2011 Sep;34(9):e147.

73 Rasekhi H, Karandish M, Jalali MT, Mohammad-Shahi M, Zarei M, Saki A, et al. The effect of vitamin K1 supplementation on sensitivity and insulin resistance via osteocalcin in prediabetic women: a double-blind randomized controlled clinical trial. Eur J Clin Nutr. 2015 Aug;69(8):891-5.

74 Yoshida M, Jacques PF, Meigs JB, Saltzman E, Shea MK, Gundberg C, et al. Effect of vitamin $\mathrm{K}$ supplementation on insulin resistance in older men and women. Diabetes Care. 2008 Nov:31(11):2092-6.

75 Dalmeijer GW, van der Schouw YT, Magdeleyns E, Ahmed N, Vermeer C, Beulens JW. The effect of menaquinone-7 supplementation on circulating species of matrix Gla protein. Atherosclerosis. 2012 Dec;225(2):397402.

76 Kumar R, Binkley N, Vella A. Effect of phylloquinone supplementation on glucose homeostasis in humans. Am J Clin Nutr. 2010 Dec;92(6):1528-32.

77 Schurgers LJ, Teunissen KJ, Hamulyák K, Knapen MH, Vik H, Vermeer C. Vitamin Kcontaining dietary supplements: comparison of synthetic vitamin K1 and natto-derived menaquinone-7. Blood. 2007 Apr;109(8): 3279-83.

78 Brandenburg VM, Reinartz S, Kaesler N, Krüger T, Dirrichs T, Kramann R, et al. Slower progress of aortic valve calcification with Vitamin K supplementation: results from a prospective interventional proof-of-concept study. Circulation. 2017 May 23;135(21): 2081-3.

79 Oikonomaki T, Papasotiriou M, Ntrinias T, Kalogeropoulou C, Zabakis P, Kalavrizioti D, et al. The effect of vitamin K2 supplementation on vascular calcification in haemodialysis patients: a 1-year follow-up randomized trial. Int Urol Nephrol. 2019 Nov;51(11): 2037-44.

80 Kurnatowska I, Grzelak P, Masajtis-Zagajewska A, Kaczmarska M, Stefańczyk L, Vermeer C, et al. Effect of vitamin K2 on progression of atherosclerosis and vascular calcification in nondialyzed patients with chronic kidney disease stages 3-5. Pol Arch Med Wewn. 2015 Jul;125(9):631-40.

81 Witham MD, Lees JS, White M, Band M, Bell S, Chantler DJ, et al. Vitamin K supplementation to improve vascular stiffness in CKD: the K4Kidneys randomized controlled trial. J Am Soc Nephrol. 2020 Oct;31(10):2434-45.

82 Zwakenberg SR, de Jong PA, Bartstra JW, van Asperen R, Westerink J, de Valk H, et al. The effect of menaquinone-7 supplementation on vascular calcification in patients with diabetes: a randomized, double-blind, placebocontrolled trial. Am J Clin Nutr. 2019 Oct; 110(4):883-90.

83 Mansour AG, Hariri E, Daaboul Y, Korjian S, El Alam A, Protogerou AD, et al. Vitamin K2 supplementation and arterial stiffness among renal transplant recipients-a single-arm, single-center clinical trial. J Am Soc Hypertens. 2017 Sep;11(9):589-97.

84 Braam LA, Knapen MH, Geusens P, Brouns F, Hamulyák K, Gerichhausen MJ, et al. Vitamin K1 supplementation retards bone loss in postmenopausal women between 50 and 60 years of age. Calcif Tissue Int. 2003 Jul;73(1): 21-6.

85 Iwamoto I, Kosha S, Noguchi S, Murakami M, Fujino T, Douchi T, et al. A longitudinal study of the effect of vitamin $\mathrm{K} 2$ on bone mineral density in postmenopausal women: a comparative study with vitamin D3 and estrogenprogesin therapy. Maturitas. 1999 Jan;31(2): 161-4.

86 Iwamoto J, Takeda T, Ichimura S. Effect of combined administration of vitamin D3 and vitamin $\mathrm{K} 2$ on bone mineral density of the lumbar spine in postmenopausal women with osteoporosis. J Orthop Sci. 2000 Nov;5(6): $546-51$.

87 Nishiguchi S, Shimoi S, Kurooka H, Tamori A, Habu D, Takeda T, et al. Randomized pilot trial of vitamin $\mathrm{K} 2$ for bone loss in patients with primary biliary cirrhosis. J Hepatol. 2001 Oct;35(4):543-5.

88 Sato Y, Honda Y, Kuno H, Oizumi K. Menatetrenone ameliorates osteopenia in disuseaffected limbs of vitamin D- and K-deficient stroke patients. Bone. 1998 Sep;23(3):291-6.

89 Sasaki N, Kusano E, Takahashi H, Ando Y, Yano K, Tsuda E, et al. Vitamin K2 inhibits glucocorticoid-induced bone loss partly by preventing the reduction of osteoprotegerin (OPG). J Bone Miner Metab. 2005 Jan;23(1): 41-7.

90 Ishida Y, Kawai S. Comparative efficacy of hormone replacement therapy, etidronate, calcitonin, alfacalcidol, and vitamin $\mathrm{K}$ in postmenopausal women with osteoporosis: the Yamaguchi Osteoporosis Prevention Study. Am J Med. 2004 Oct;117(8):549-55.

91 Iwamoto J, Takeda T, Ichimura S. Effect of menatetrenone on bone mineral density and incidence of vertebral fractures in postmenopausal women with osteoporosis: a comparison with the effect of etidronate. J Orthop Sci. 2001;6(6):487-92.

92 Cheung AM, Tile L, Lee Y, Tomlinson G, Hawker G, Scher J, et al. Vitamin K supplementation in postmenopausal women with osteopenia (ECKO Trial): a randomized controlled trial. PLoS Med. 2008 Oct;5(10):e196.

93 Braam LA, Knapen MH, Geusens P, Brouns F, Vermeer C. Factors affecting bone loss in female endurance athletes: a two-year followup study. Am J Sports Med. 2003 Nov-Dec; 31(6):889-95.

94 Knapen MH, Schurgers LJ, Vermeer C. Vitamin K2 supplementation improves hip bone geometry and bone strength indices in postmenopausal women. Osteoporos Int. 2007 Jul;18(7):963-72.

95 Booth SL, Dallal G, Shea MK, Gundberg C, Peterson JW, Dawson-Hughes B. Effect of vitamin $\mathrm{K}$ supplementation on bone loss in elderly men and women. J Clin Endocrinol Metab. 2008 Apr;93(4):1217-23.

96 Inoue T, Fujita T, Kishimoto H, Makino T, Nakamura T, Nakamura T, et al. Randomized controlled study on the prevention of osteoporotic fractures (OF study): a phase IV clinical study of 15-mg menatetrenone capsules. J Bone Miner Metab. 2009 Dec;27(1):66-75.

97 Theuwissen E, Cranenburg EC, Knapen MH, Magdeleyns EJ, Teunissen KJ, Schurgers LJ, et al. Low-dose menaquinone-7 supplementation improved extra-hepatic vitamin $\mathrm{K}$ status, but had no effect on thrombin generation in healthy subjects. Br J Nutr. 2012 Nov; 108(9):1652-7.

98 Theuwissen E, Teunissen KJ, Spronk HM, Hamulyák K, Ten Cate H, Shearer MJ, et al. Effect of low-dose supplements of menaquinone-7 (vitamin K2 ) on the stability of oral anticoagulant treatment: dose-response relationship in healthy volunteers. J Thromb Haemost. 2013 Jun;11(6):1085-92.

99 De Vriese AS, Caluwé R, Pyfferoen L, De Bacquer D, De Boeck K, Delanote J, et al. Multicenter randomized controlled trial of vitamin $\mathrm{K}$ antagonist replacement by rivaroxaban with or without vitamin K2 in hemodialysis patients with atrial fibrillation: the Valkyrie Study. J Am Soc Nephrol. 2020 Jan;31(1): 186-96. 